\title{
Land consolidation in mountain areas. Case study from southern Poland
}

\author{
Jarosław Janus*, Magdalena Lopacka, Ewa John \\ University of Agriculture in Kraków \\ Faculty of Environmental Engineering and Land Surveying \\ Department of Agricultural Land Surveying, Cadastre and Photogrammetry \\ ul. Balicka 253a, 30-198 Kraków, Poland \\ e-mails: j.janus@ur.krakow.pl; magdalena.lopacka@gmail.com; john.ewa@wp.pl
}

Jarosław Janus: https://orcid.org/0000-0003-1725-1589

* Corresponding author: Jarosław Janus

Received: 31 March 2017 / Accepted: 14 August 2017

\begin{abstract}
Land consolidation procedures are an attempt to comprehensively change the existing spatial structure of land in rural areas. This treatment also brings many other social and economic benefits, contributing to the development of consolidated areas. Land consolidation in mountain areas differs in many respects from those implemented in areas with more favorable conditions for the functioning of agriculture. The unfavorable values of land fragmentation indices, terrain conditions and lower than the average soil quality affect both the dominant forms of agricultural activity and the limited opportunities to improve the distribution of plots in space, parameters of shape, and the area as a result of land consolidation. For this reason, the effectiveness of land consolidation in mountain areas can be achieved by improving the quality of transportation network and the accessibility of the plots, arranging ownership issues and improving the quality of cadastral documentation.

This article presents the evaluation of the measures of effectiveness of land consolidation realized in mountain areas on the example of Łetownia Village in the Małopolska Province, located in the southern part of Poland. Selected village is an area with unfavorable conditions for the functioning of agriculture and high values of land fragmentation indices.
\end{abstract}

Key words: land fragmentation, land consolidation, consolidation efficiency, rural areas

\section{Introduction}

High fragmentation of spatial structure is one of the most important factors that have negative impact on economical aspects of agriculture functioning (Manjunatha et al., 2013, Rahman and Rahman, 2009). Unfavorable shapes and sizes of plots 
significantly lower possible income (Gonzalez et al., 2007), what is also true for homesteads characterized by long distances between its elements (Found, 1970). Gradual deterioration of rural areas spatial structure is a result of multigenerational changes. Most often, the changes are caused by land inheritance, very seldom they result from selling fragments of existing lands. An important role in land fragmentation is also played by spatial distribution of soils of different quality (Sklenicka and Salek, 2008). This caused, even at the beginning of villages development, initial fragmentation of a homestead into sections based on different soil suitability for crops. Finally, the demographic changes have additional impact on land fragmentation indices.

Complex changes of the plots spatial structure can be achieved through land consolidation processes (Pašakarnis and Maliene, 2010; Markuszewska, 2013). However, the procedures of their implementation vary in different countries. The dissimilarities are caused by different legislature as well as social and historical factors (Vitikainen, 2004). Because of the differences in the processes and the types of consolidation works it is difficult to objectively compare and assess their effectiveness (Janus and Markuszewska, 2017). There are however certain characteristics that allow to determine universal categories of consolidation processes including: factors describing village settlement type, type of built-up area, type of agricultural production, geographical coefficients, as well as social and demographical conditions. The villages located in mountain and submountain areas possess most of these characteristics. The indices of land fragmentation are generally less favorable in these areas, the quality of soils is relatively poor, and semi-subsistence farms prevail. Consequently, land consolidation works require different approach. Most often, their main purpose is not rising farming profitability but improving the non-economic conditions of homesteads functioning, such as developing the density and quality of transportation network (Paige-Green, 2006), road accessibility (Janus et al., 2017), preventing water erosion, and organizing cadastral documentation. The ecological aspects of land fragmentation in such areas can also be shaped during consolidation processes (Zhang et al., 2012; Yin et al., 2011). The abovementioned categories should also be applied to accomplished consolidation works, but it is relatively difficult to represent them with measurable indicators.

\section{Land fragmentation indices}

A set of different approaches and methods can be used to assess structural changes that took place in a village and which resulted from land consolidation works. Land fragmentation indices are used most frequently (Bentley, 1987). The indices can have various forms: from relatively simple, which take into account the number of plots and their sizes, to complex, which consider also the shapes of plots and their spatial distribution (Gonzalez et al., 2004). The most complex indices allow for a synthetic analysis of a wide spectrum of factors, including for example road accessibility 
(Demetriou et al., 2013). A separate category of indices assesses the costs of farming which are affected by the areas and shapes of plots (Janus et al., 2016). Other approaches consider social (Cay et al., 2010), environmental (Zhang and Zhao, 2007), and landscape factors (Muchová and Petrovič, 2010).

The suggested attempt in assessing the effects of land consolidation works that took place in mountain areas is based on quantitative evaluation of various aspects. The first one was the change in values of four chosen indices. Two of the most frequently used indices consider the number of plots and their areas: Simpson index (Blarel et al., 1992) and Januszewski index (Januszewski, 1968). The other two take into account spatial distribution of plots in homesteads: average distances of hectares index $\left(a v d h a_{i}\right)$ and grouping index (Latruffe and Piet, 2014).

The second aspect of the assessment considers the changes that took place in transportation network of the areas involved in consolidation works. The analysis of transportation network is not only an element of consolidation works assessment, but also a tool used in spatial analyses of areas in which consolidation works should be implemented (Janus and Taszakowski, 2015). In this study the changes in the intensity of road inaccessibility phenomenon were measured along with changes in the length and density of the network.

The third aspect of this study is to show changes in the boundary shape of builtup areas. Such areas are generally excluded during the reorganization of plots through land consolidation. The only exception is the new measurement of the boundaries. This set of data represents the effects that consolidation works have on cadastral data updating.

\section{Case study}

The area studied is a part of Łetownia Village located in southern, mountain part of Poland. Land consolidation works took place there in years 2010-2014. Before consolidation, the area of 981 ha was fragmented into 5356 plots. The location of the area is shown in Figure 1. Figure 2 shows plots structure before and after consolidation, relief map, slope map, and orthophotomap. The area that underwent consolidation consists of ordinary homesteads as well as numerous lands belonging to non-agricultural owners and institutions. Therefore, it was not desirable to calculate the parameters of fragmentation for the entire dataset as it would not show correctly the results of structural reorganization of the plots used for agricultural purposes only. For this reason, the analysis was narrowed to a data set that comprises 10 largest homesteads with farmsteads identified in the analyzed area. 


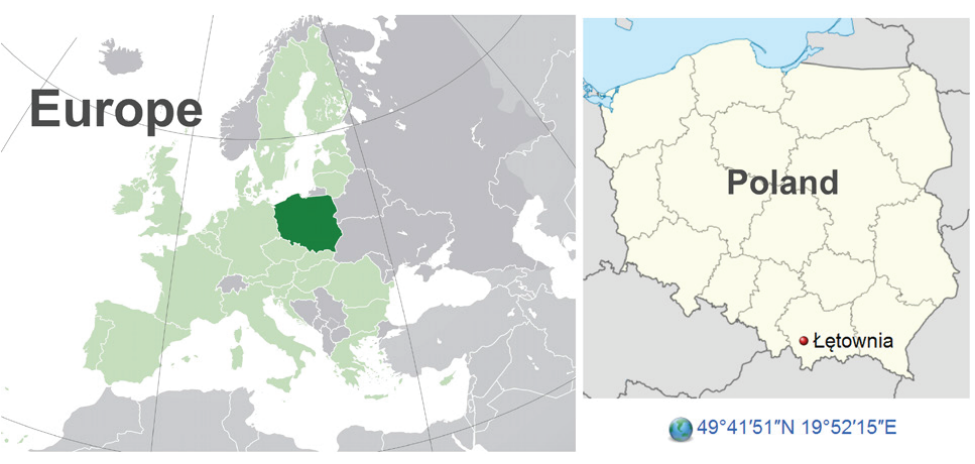

Fig. 1. Location of the study area in Europe and in Poland
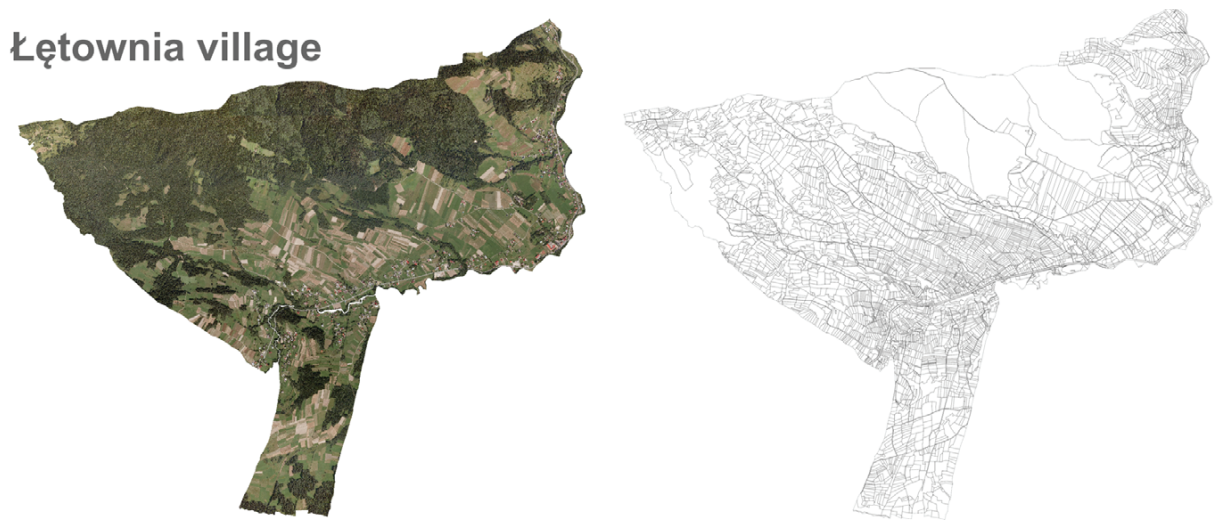

製
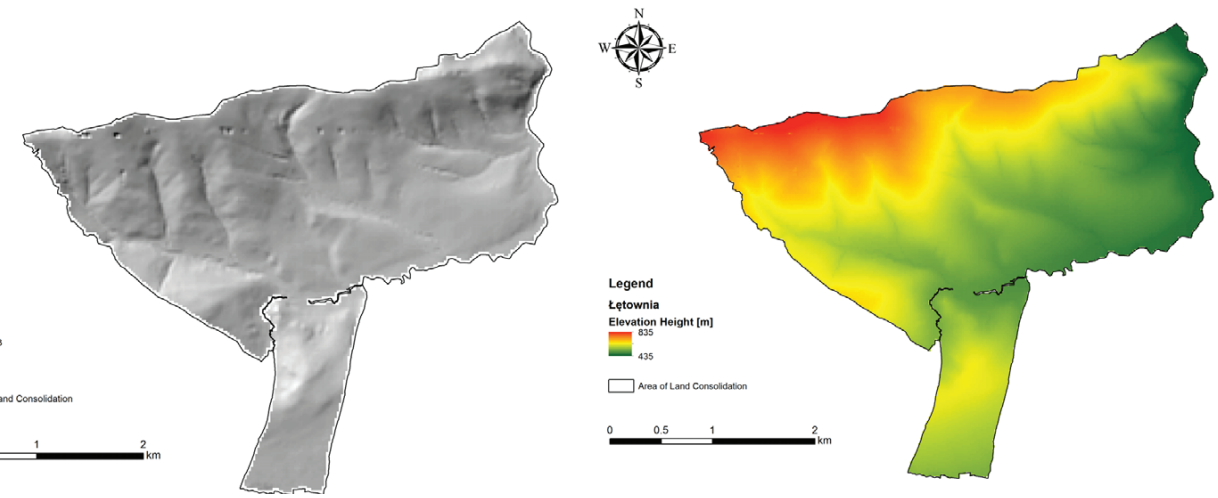

Fig. 2. Chosen aspects of the spatial structure of lands in the study area 


\section{Results}

The first stage in the computational process was to calculate the values of selected fragmentation indices for the plot structure before and after consolidation. Spatial analysis tools used as part of the MkScal software package (Janus and Zygmunt, 2016) were used for this purpose. The distribution of land selected for the analysis of the largest homesteads is shown in Figure 3. The basic parameters of the fragmentation of these homesteads are shown in Table 2. The obtained values of the fragmentation indices are shown in Table 3.
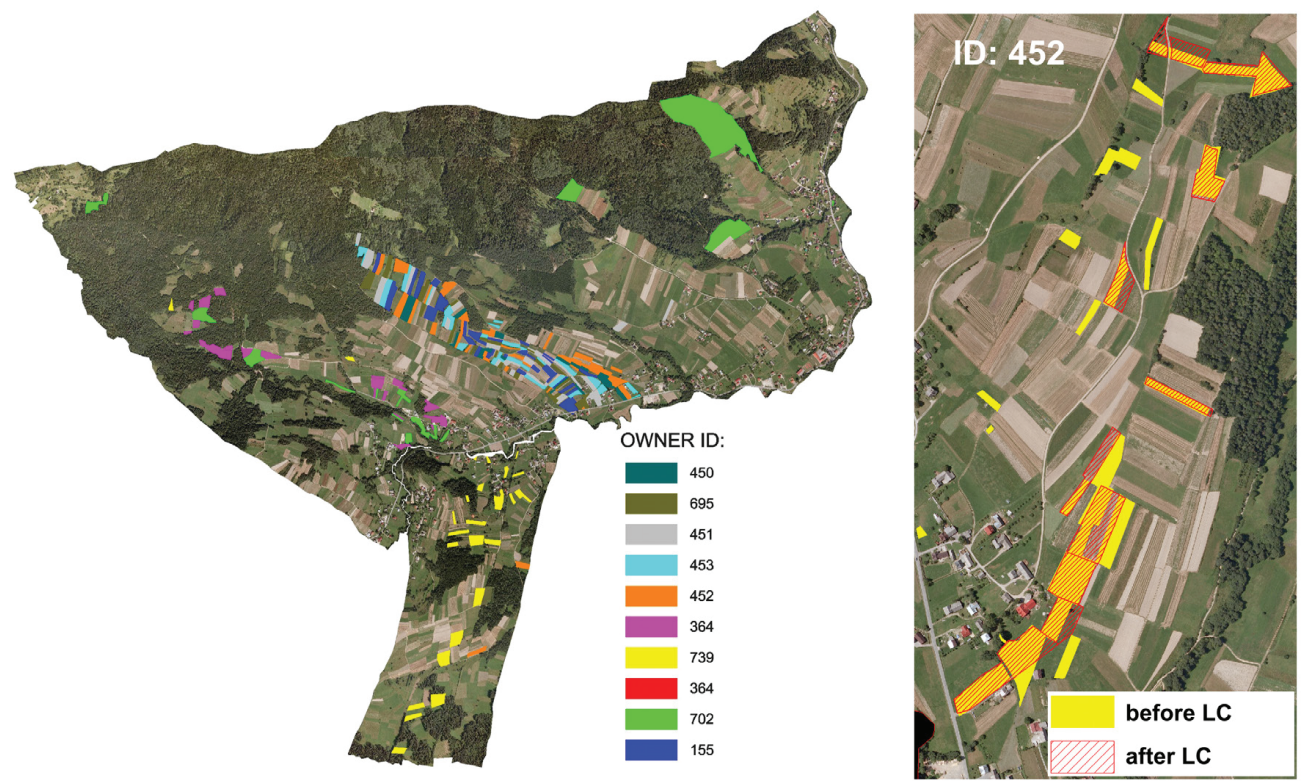

Fig. 3. Distribution of plots belonging to the analyzed group of 10 largest homesteads and an example of changes to this distribution as a result of land consolidation

Table. 1. Values of selected parameters of chosen homesteads before and after consolidation

\begin{tabular}{|c|c|c|c|c|c|c|c|c|c|}
\hline & \multicolumn{3}{|c|}{ Area [ha] } & \multicolumn{3}{c|}{ No. of plots } & \multicolumn{3}{c|}{ Average plot area [ha] } \\
\hline Farm id & A & B & $\Delta(\%)$ & A & B & $\Delta(\%)$ & A & B & $\Delta(\%)$ \\
\hline 155 & 5.23 & 8.22 & 57.17 & 52 & 28 & -46.15 & 0.1 & 0.29 & 190.00 \\
\hline 346 & 5.36 & 6.07 & 13.25 & 55 & 32 & -41.82 & 0.1 & 0.19 & 90.00 \\
\hline 364 & 3.97 & 3.43 & -13.60 & 44 & 12 & -72.73 & 0.09 & 0.29 & 222.22 \\
\hline 450 & 2.72 & 2.6 & -4.41 & 42 & 9 & -78.57 & 0.06 & 0.29 & 383.33 \\
\hline 451 & 5.04 & 5.08 & 0.79 & 44 & 19 & -56.82 & 0.11 & 0.27 & 145.45 \\
\hline 452 & 6.33 & 6.19 & -2.21 & 66 & 20 & -69.70 & 0.1 & 0.31 & 210.00 \\
\hline 453 & 4.25 & 4.06 & -4.47 & 38 & 18 & -52.63 & 0.11 & 0.23 & 109.09 \\
\hline 695 & 3.08 & 2.99 & -2.92 & 38 & 13 & -65.79 & 0.08 & 0.23 & 187.50 \\
\hline 702 & 15.98 & 15.95 & -0.19 & 51 & 17 & -66.67 & 0.31 & 0.94 & 203.23 \\
\hline 739 & 5.46 & 6.85 & 25.46 & 40 & 38 & -5.00 & 0.14 & 0.18 & 28.57 \\
\hline
\end{tabular}


Changes in the area of homesteads during the process of land consolidation are most often caused by the simultaneous trade of land between owners (sometimes with the use of state or local land) and by merging or dividing the land within one family. Statistically, these are not major changes and this is also true for the analyzed group of homesteads. Significant changes (over 20\%) affected only two homesteads; in one case it was an increase of more than 50\%. The reduction in the number of plots in the analyzed group of homesteads is similar and ranges from $41.82 \%$ to $78.57 \%$. Analogous variability refers to the average area of plots. It increased in size (also with one exception) in the range of $90 \%$ to $383 \%$.

Table. 2. Values of selected fragmentation indices in the analyzed group of homesteads before and after consolidation

\begin{tabular}{|c|c|c|c|c|c|c|c|c|c|c|c|c|}
\hline & \multicolumn{3}{|c|}{ Simpson index } & \multicolumn{3}{|c|}{ Januszewski index } & \multicolumn{2}{c|}{$\begin{array}{l}\text { Average distances of } \\
\text { hectares index }\end{array}$} & \multicolumn{3}{|c|}{ Grouping index } \\
\hline Farm id & $\mathrm{A}$ & $\mathrm{B}$ & $\Delta(\%)$ & $\mathrm{B}$ & $\mathrm{A}$ & $\Delta(\%)$ & $\mathrm{A}$ & $\mathrm{B}$ & $\Delta(\%)$ & $\mathrm{A}$ & $\mathrm{B}$ & $\Delta(\%)$ \\
\hline 155 & 0.04 & 0.07 & 75.00 & 0.15 & 0.21 & 40.00 & 0.41 & 1.23 & 200.00 & 5.68 & 11.82 & 108.10 \\
\hline 346 & 0.06 & 0.06 & 0.00 & 0.16 & 0.2 & 25.00 & 0.69 & 0.7 & 1.45 & 8.58 & 17.1 & 99.30 \\
\hline 364 & 0.04 & 0.11 & 175.00 & 0.16 & 0.3 & 87.50 & 0.57 & 0.51 & -10.53 & 8.02 & 8.93 & 11.35 \\
\hline 450 & 0.05 & 0.16 & 220.00 & 0.17 & 0.35 & 105.88 & 0.46 & 0.46 & 0.00 & 8.03 & 7.35 & -8.47 \\
\hline 451 & 0.04 & 0.06 & 50.00 & 0.16 & 0.24 & 50.00 & 0.55 & 0.54 & -1.82 & 8.06 & 8.13 & 0.87 \\
\hline 452 & 0.03 & 0.06 & 100.00 & 0.13 & 0.23 & 76.92 & 0.59 & 0.58 & -1.69 & 12.37 & 12.72 & 2.83 \\
\hline 453 & 0.04 & 0.08 & 100.00 & 0.18 & 0.25 & 38.89 & 0.47 & 0.47 & 0.00 & 8.16 & 8.42 & 3.19 \\
\hline 695 & 0.06 & 0.1 & 66.67 & 0.18 & 0.29 & 61.11 & 0.49 & 0.51 & 4.08 & 8.05 & 7.54 & -6.34 \\
\hline 702 & 0.27 & 0.27 & 0.00 & 0.22 & 0.32 & 45.45 & 0.95 & 0.95 & 0.00 & 13.6 & 13.61 & 0.07 \\
\hline 739 & 0.05 & 0.04 & -20.00 & 0.17 & 0.18 & 5.88 & 0.54 & 0.56 & 3.70 & 17.7 & 15.96 & -9.83 \\
\hline
\end{tabular}

The changes are not large. Moreover, in the studied area, before consolidation, the phenomenon of plots belonging to one owner and adjacent to one another is intensive. Therefore, it affects the values of the fragmentation indices. In practice, this means that changes in both the number of plots and their average areas are even smaller than those calculated on the basis of the cadastral plots analysis.

The large changes in the Simpson index and Januszewski index indicate their inadequacy to assess the effects of consolidation in the cases of an intense occurrence of neighboring plots. Their construction is based largely on the analysis of the number of plots and their areas. Reliable evaluation of fragmentation changes using these indices is possible only after consolidation of neighboring plots belonging to individual owners, which would result in a reduction of their number and an increase of their areas.

The next two indices are free of these disadvantages. The variability of the average distances of hectares index does not exceed $11 \%$ (with one exception at $200 \%$ ). In practice, this means that no significant changes took place in the spatial distribution of land. This index reflects well the extent of actual changes in the spatial distribution of homesteads, which most often come down to combining smaller plots into larger 
and making minor corrections of their locations. Similar conclusions can be drawn from the analysis of the results of the last used index (grouping index). In this case, except for two homesteads, the changes in the index values range from -10 to $+11 \%$, meaning that they are also very low.

The second of the consolidation effects considered is the change in transportation network parameters (length and density) and changes in the accessibility of plots to the road network. The effects of land consolidation for this case are presented in Table 3 and in Figures 4 and 5.

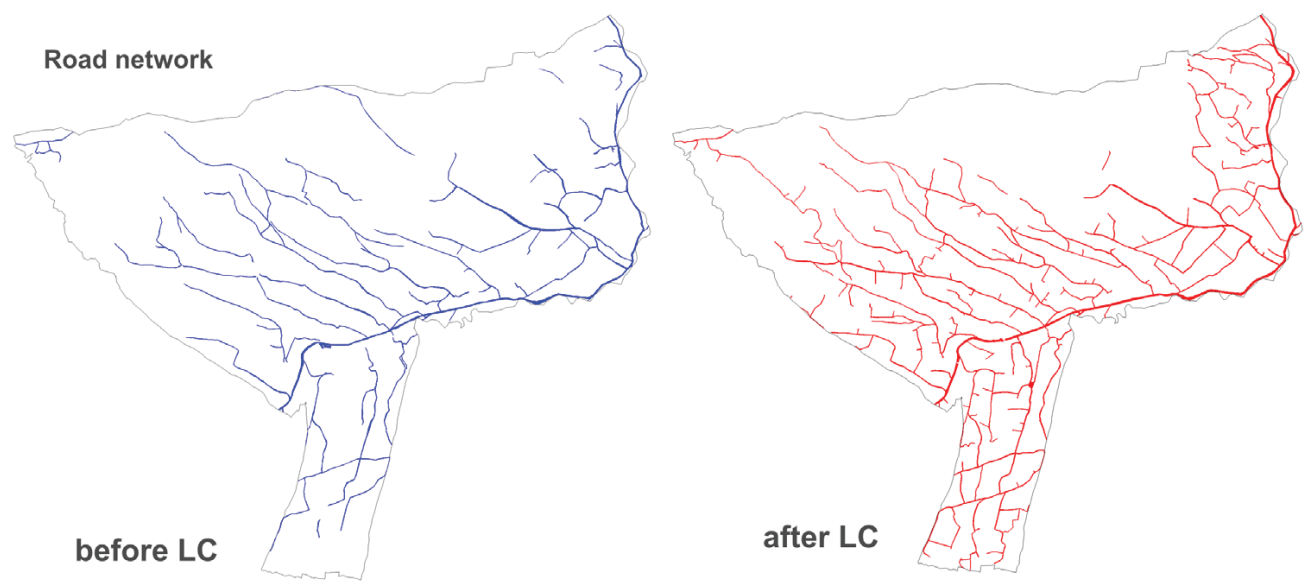

Fig. 4. Changes of the spatial structure of the road network as a result of the analyzed land consolidation

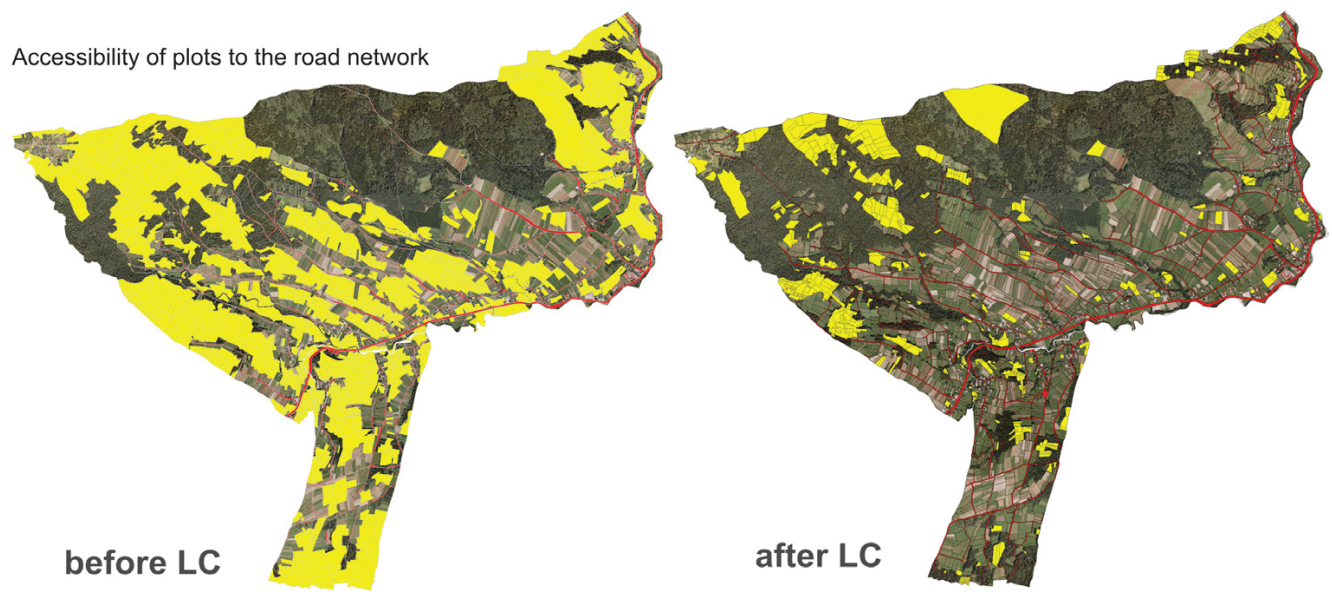

Fig. 5. Changes in the accessibility of plots to the road network as a result of the analyzed land consolidation 
Table 3. Changes of chosen parameters related to the road network as a result of consolidation

\begin{tabular}{|c|c|c|c|c|c|c|c|c|}
\hline & $\begin{array}{c}\text { No. of } \\
\text { plots }\end{array}$ & $\begin{array}{c}\text { Area of } \\
\text { plots } \\
{[\text { ha] }]}\end{array}$ & $\begin{array}{c}\text { No. of plots } \\
\text { without } \\
\text { accessibility } \\
\text { to the road } \\
\text { network }\end{array}$ & $\begin{array}{c}\text { Change } \\
(\%)\end{array}$ & $\begin{array}{c}\text { Area of } \\
\text { plots without } \\
\text { accessibility } \\
\text { to the road } \\
\text { network [ha }]\end{array}$ & $\begin{array}{c}\text { Change } \\
(\%)\end{array}$ & $\begin{array}{c}\text { Length of } \\
\text { the road } \\
\text { network } \\
{[\mathrm{km}]}\end{array}$ & $\begin{array}{c}\text { Density } \\
\text { of the } \\
\text { road } \\
\text { network } \\
{[\mathrm{km} / \mathrm{ha}]}\end{array}$ \\
\hline Before LC & 5356 & 981 & 3037 & 56.70 & 400.66 & 40,84 & 87.30 & 0.09 \\
\hline After LC & 3096 & 981 & 550 & 17.76 & 104.78 & 10,68 & 125.05 & 0.13 \\
\hline Change & $-42,20 \%$ & 0 & $-89.82 \%$ & & $-73.85 \%$ & & $+43.24 \%$ & $+43.24 \%$ \\
\hline
\end{tabular}

The lack of access to the road network was a significant problem in the analyzed area and affected almost $60 \%$ of the total number of plots (40\% of the total area). After consolidation, this problem was reduced to nearly $18 \%$ of the number of plots $(11 \%$ of the total area). The total reduction of the number of plots affected by the lack of accessibility is high and amounts to $90 \%$. Plots that are affected by the problem even after consolidation are located either in built-up or forested areas that were not a subject complex reorganization of the plots distribution. However, it should be noticed that plots in built-up areas which have no access to the road network have other (usually in the form of land easements) rights of access to the surrounding road network.

The length of the local transportation network increased by over $43 \%$, from 87.30 to $125.05 \mathrm{~km}$, with the corresponding increase in the values of the index determining the density of the road network per hectare of the village. The creation of a new road network is related, on the one hand, to the size of changes in the spatial structure (larger changes are associated with the diminishing needs for the determination of new road network elements) and, on the other, to the limited financial resources earmarked for investment in the network.

The last of the elements that should be presented as one of the effects of the consolidation works are changes in the boundary pattern of plots in built-up area. As a rule, the built-up area is not a subject to a re-design of the property boundaries but the boundaries are measured again, and their course is then completely different than the one on maps often developed at the end of the 19th century. The scale of discrepancies illustrates the aspect of consolidation woks associated with updating cadastral databases. An exemplary fragment of the discussed land consolidation is shown in Figure 6. 

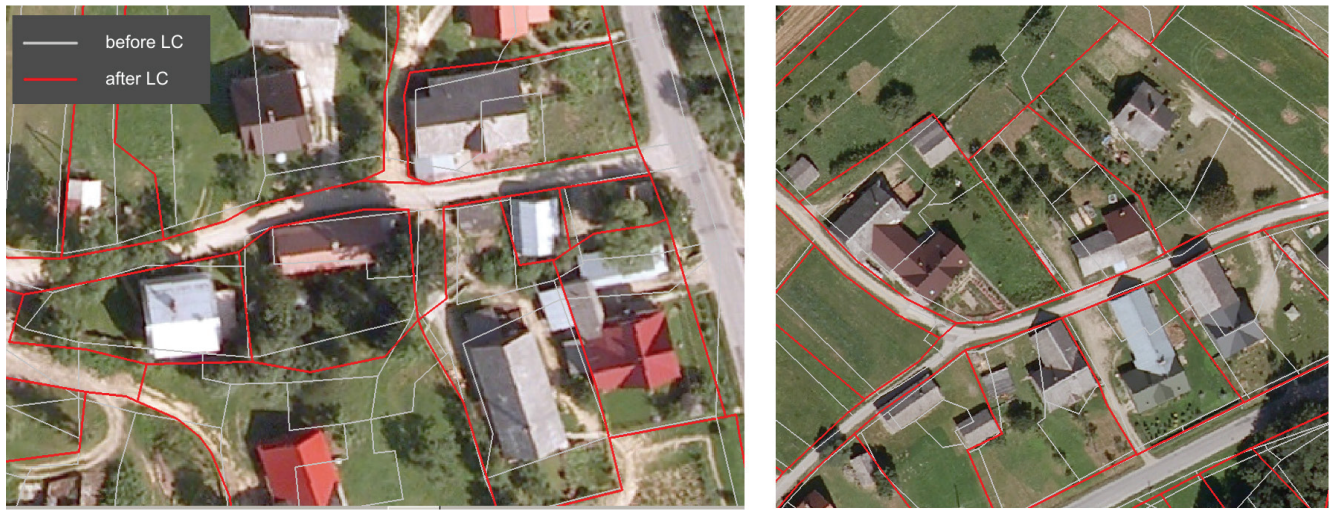

Fig. 6. Changes in border layout in built-up areas

\section{Conclusions}

A number of conclusions can be drawn from the study. Land fragmentation indices used widely for the assessment of consolidation works effectiveness are not always proper tools. The type of consolidation should determine its further assessment. The changes in the parameters of fragmentation shown with the indices are a correct approach during consolidation processes implemented in the areas where agricultural function prevails. The consolidation works are required here as they improve the functioning of homesteads and increase profitability. Different approach should be considered for consolidation works which are supposed to improve environmental conditions, increase road network density and enhance its quality, improve the quality of cadastral data, and provide good conditions for the development of the area. The changes in the boundaries layout and changes in ownership can positively affect these aspects. The development of the indices and progress in their use depending on the types of consolidation works should undergo further studies.

Another important aspect is the necessity to eliminate the phenomenon of neighboring plots that belong to given owners while using Simpson index and Januszewski index. The average distances of hectares index and grouping index are affected by the phenomenon to a much smaller extent.

\section{Acknowledgments}

The presented research is a part of 'DS 3366/KGRKiF' Project realized and financed by Department of Agricultural Land Surveying, Cadastre and Photogrammetry, University of Agriculture in Kraków. 


\section{References}

Bentley, W. (1987). Economic and ecological approaches to land fragmentation: In defense of a muchmaligned phenomenon. Annual Review of Anthropology, 16, 31-97.

Blarel, B., Hazell, P., Place, F. and Quiggin, J. (1992). The economics of farm fragmentation: evidence from Ghana and Rwanda. The World Bank Economic Review, 6, 233-254.

Cay, T., Ayten, T. and Iscan, F. (2010). Effects of different land reallocation models on the success of land consolidation projects: Social and economic approaches. Land Use Policy, 27(2), 262-269. https://doi.org/10.1016/j.landusepol.2009.03.001

Demetriou, D., Stillwell, J. and See, L. (2013). A new methodology for measuring land fragmentation. Computers, Environment and Urban Systems, 39, 71-80. https://doi.org/10.1016/j. compenvurbsys.2013.02.001

Found, W. C. (1970). Towards a general theory relating distance between farm and home to agricultural production. Geographical Analysis, 2, 165-176 x.

Gonzalez, X. P., Alvarez, C. J. and Crecente, R. (2004). Evaluation of land distributions with joint regard to plot size and shape. Agricultural Systems. https://doi.org/10.1016/j.agsy.2003.10.009

Gonzalez, X. P., Marey, M. F. and Alvarez, C. J. (2007). Evaluation of productive rural land patterns with joint regard to the size, shape and dispersion of plots. Agricultural Systems, 92(1-3), 52-62. https://doi.org/10.1016/j.agsy.2006.02.008

Latruffe, L. and Piet, L. (2014). Does land fragmentation affect farm performance? A case study from Brittany, France. Agricultural Systems, 129, 68-80. https://doi.org/10.1016/j.agsy.2014.05.005

Januszewski, J. (1968). Index of land consolidation as a criterion of the degree of concentration. Geographia Polonica, 14, 291-296.

Janus, J. and Taszakowski, J. (2015). The idea of ranking in setting priorities for land consolidation works. Geomatics, Landmanagement and Landscape, 1/2015, 31-43.

Janus, J., Głowacka, A. and Bozek, P. (2016). Identification of areas with unfavorable agriculture development conditions in terms of shape and size of parcels with example of Southern Poland. $15^{\text {th }}$ International Scientific Conference ENGINEERING FOR RURAL DEVELOPMENT Proceedings, Volume 15 May 25-27, 2016, 1260-1265.

Janus, J. and Zygmunt, M. (2016). MKSCAL - System for land consolidation project based on Cad platform. Geomatics, Landmanagement and Landscape, 2/2016(2), 49-59.

Janus, J., Mika, M., Leń, P., Siejka, M. and Taszakowski, J. (2016). A new approach to calculate the land fragmentation indicators taking into account the adjacent plots. Survey Review. DOI:10.1080/00396 265.2016.1210362 Published online: 27 Jul 2016

Janus, J. Bozek, P. Taszakowski, J. and Glowacka, A. (2017). Road accessibility problem as A part of land consolidation planning. 16th International Scientific Conference ENGINEERING FOR RURAL DEVELOPMENT Proceedings, Volume 16 May 24-26, 2017, DOI: 10.22616/ERDev2017.16.N221, pp. $1052-1057$.

Janus, J. and Markuszewska, I. (2017). Land consolidation - A great need to improve effectiveness. A case study from Poland. Land Use Policy, DOI: https://10.1016/j.landusepol.2017.03.028

Manjunatha, A. V., Anik, A. R., Speelman, S. and Nuppenau, E. A. (2013). Impact of land fragmentation, farm size, land ownership and crop diversity on profit and efficiency of irrigated farms in India. Land Use Policy, 31, 397-405. https://doi.org/10.1016/j.landusepol.2012.08.005

Markuszewska, I. (2013). Land Consolidation As An Instrument Of Shaping The Agrarian Structure In Poland: A Case Study Of The Wielkopolskie And Dolnośląskie Voivodeships. Quaestiones Geographicae, 32, 53-67.

Muchová, Z. and Petrovič, F. (2010). Changes in the landscape due to land consolidations. Ekologia Bratislava, 29(2), 140-157. https://doi.org/10.4149/ekol-2010-02-140

Pašakarnis, G. and Maliene, V. (2010). Towards sustainable rural development in Central and Eastern Europe: Applying land consolidation. Land Use Policy, 27(2), 545-549. https://doi.org/10.1016/j. landusepol.2009.07.008 
Paige-Green, P. (2006). Appropriate Roads for Rural Access. Gulf Conference on Roads, Proceedings of the Third, 1-10. Retrieved from http:/www4.worldbank.org/afr/ssatp/Resources/HTML/LVSR/ English/Added-2007/2006-Appropr-Rural-Roads-by-PPaigeGreen.pdf

Rahman, S. and Rahman, M. (2009). Impact of land fragmentation and resource ownership on productivity and efficiency: The case of rice producers in Bangladesh. Land Use Policy, 26(1), 95-103. https:// doi.org/10.1016/j.landusepol.2008.01.003

Sklenicka, P. and Salek, M. (2008). Ownership and soil quality as sources of agricultural land fragmentation in highly fragmented ownership patterns. Landscape Ecology, 23(3), 299-311. https:// doi.org/10.1007/s10980-007-9185-4

Vitikainen, A. (2004). An Overview of Land Consolidation in Europe. Nordic Journal of Surveying and Real Estate Research, 1(1), 25-44.

Yin, S., Wei, C. F., Yang, X. Y. and Luo, Y. J. (2011). The ecological compensation of land consolidation and its evaluation in hilly area of southwest China. In Energy Procedia (Vol. 5, pp. 1192-1199). https://doi.org/10.1016/j.egypro.2011.03.209

Zhang, Q., Luo, H. and Yan, J. (2012). Integrating biodiversity conservation into land consolidation in hilly areas - A case study in southwest China. Acta Ecologica Sinica, 32(6), 274-278. https://doi. org/10.1016/j.chnaes.2012.06.002

Zhang, Z. and Zhao, W. (2007). Effects of land consolidation on ecological environment. Transactions of the Chinese Society of Agricultural Engineering, 23(8), 281-285. 
